\title{
医療安全確保のための現場の取組みと法制度 一特に事故報告制度を中心に一
}

\author{
THE HOSPITAL EFFORTS AND LEGAL SYSTEMS FOR MEDICAL SAFETY \\ -MAINLY FOCUSING ON REPORTING SYSTEM
}

\author{
畑中 綾子 ${ }^{1}$ \\ ${ }^{1}$ LL.M. (法学) 社会技術研究開発センター 法システム研究グループ (E-mail:jj96130@j.u-tokyo.ac.jp)
}

\begin{abstract}
医療機関は，安全で質の高い医療を提供すべく，日々努力している．しかし，兴の努力は，なかなか社 会に認知されることなく, 医療事故やミスといった報道ばかりが目に付く. 本研究は, 昨年 10 月より新た に始まった医療事故の強制報告制度を通じて，医療現場の具体的場安全対策や取組みを，法学研究者の視 点からインタビューをもとに記述することを目的とする．医療現場の複雑さは，医療資源の配分問題や診 療報酬制度など法制度の仕組みとも深い関係がある。この研究によって，医療現場の取組みを評価し，現 場と法制度のよい方向への連関を提言していきたい，さらに，将来的な医療政策への提言にもつなげてい きたいと考える .
\end{abstract}

キーワード：事故報告制度，医療安全対策，医療資源の配分，医療機能評価

\section{1. はじめに}

医療機関と医療従事者は, 日々，安全て質の高い医療 を提供する努力をしている.多くの業務を抱え，多忙な 毎日を送っている中，医療費削减や事故報告制度によっ て , 業務負担はさらに増えているの力現状である。

このような現状のもと , 医療機関では, 具体的にどの ような安全対策がなされ，どのような行動をとっている のか . この点 , 社会の目からは明らかではない . 今後 , 医療現場は社会との連携を行いながら体制構築, 整備を 行う必要がある. 乥こで, 社会に医療現場の取組みを伝 えることが, よりより医療の実現のために必要ではない か. 医療現場ではどのような取組を行っているのか, 法 学研究者の視点から調査を行ったのか泍研究である.

平成 16年度, 社会技術研究システム法システム研究グ ループと医療安全研究グループの横断研究により, 国立 大学病院インタビューを実施した . さらに, 医療事故と 法制度ワークショップを開催して, 現場と政策担当者, 専門家の立場からコメントを頂いた .

本稿は，これら横断研究で結果を筆者なりにまとめ たものである .

\section{2. 本研究の概要}

本研究では, 国立大学病院における医療安全管理者を 中心としたインタビューおよびワークショップでの意見
を中心に構成される．

\section{1. 国立大学病院インタビュー}

インタビューは, 2004 年 8 月より 2005 年1月まで， 国立大学 4 病院 (東京大学, 京都大学, 北海道大学, 東 北大学) で行っだ）.インタビュー対象者は, 病院長 2 名, 医師・安全管理者 7 名, 看護師・安全管理者 8 名, 保健学・医療管理学研究者 2 名, 医事課長 1 名という構 成である.また, 追加的に行った, 地方自治体立病院 (大 津市民病院) ,宮城県の訪問医のインタビューの結果も一 部で利用している。

インタビューの方法は具体的な医療安全対策や事故報 告制度への取り組み，現場て抱える問題点など，質問紙 をあらかじめ送付したうえで, 一人 1-2 時間, 自由に発 言して頂いた .また医療従事者を志したきつかけなど， インタビュイーの背景や感情もできるだけ発言していた だくように努めた .

\section{2. 医療事故報告と法制度ワークショップの開催}

横断研究の一環として，2004 年 11 月に医療事故報告と 法制度ワークショップを開催した . 医療安全研究グループ より，「具体的な東大病院で医療安全の取組みについて」 法システム研究グループより，「事故報告と異状死届出」,

「国立大学病院インタビューをもとにした各病院の取組み についての報告を行った .ワークショップのコメンテー ターとして, 行政官, 医療現場の医師, 安全管理者, 弁護 
$士$,医事法研究者など多方面の関係者から二澺見を頂いた． 本稿ではークショップ参加者の意見も参考にしている .

\section{3. 事故報告制度の影響と問題点}

\section{1. 病院内における事故報告制度}

(1) オンライン導入

医療事故報告は，まず，医療機関の内部ての事故報告 制度の充実か前提となる. 院内の報告制度の整備につい ては,平成 12 年 4 月施行「医療法施行規則の一部を改正 する省令」により，特定機能病院の承認要件に医療事故 等の院内報告・調査分析 - 周知徹底のシステム整備か加 わった.平成 14 年には, すべての病院と有床診療所に院 内報告制度の整備力義務付けられている。

これにより平成 12 年から，国立大学病院では，院内報 告制度力嫁動した. 当初は, 記述内容が多いこと, 当事 者面接を要求する書式て時間がかかなどの問題もあつ た ${ }^{1)}$. 乥こで，いくつかの病院で，迅速な報告と個人 か特定されない仕組みのオンライン報告制度の導入があ つた．すでにオンライン報告を導入しているのは, 平成 14 年の東北大, 平成 15 年の北大である. 他の病院でも 導入の検討段階には入っている.

北大病院を例にあげると 平成 15 年 4 月 1 日の才ンラ イン導入により，インシデント報告における医師の報告 数の割合か増加するという影響があつた .

インシデントレポートは, 重大な事故に至らなかった 事案について提出するものである (ヒヤリハット報告と (うこともある) 院内報告の多〈はインシデントレポー トであり，年間 3000-4000 件を処理する医療機関もあつ た .このインシデントレポートの報告者は，いずれの病 院も看護師が 9 割を占める. 炎の理由としては, 光も光 も看護師の医療従事者に占める人数が多いこと, 患者と 接する時間の長さにあるのではないかとのことであった また, 輸夜注射や内服薬の予約, チューブドレーンの管 理など最終的な行為の実施者であることにも関連する． 看護師は組織のヒエラルキー構造か強く, 看護部からの 指示力行き渡りやすいこと, 病院間の異動があまりない ため帰属意識力強いことも理由ではないかと指摘された ただ，文化的背景や職種の違いを加味しても，医師の報 告割合か低いことは,いずれの病院でも問題視されてお り,3-4\%に留まっていた病院もあった .これに対し，患 者への影響度の重要事例報告については, 医師の報告が $75 \%$ を超えており，医師は重大な結果か起きた場合には 報告を行うものと評価できる .

北大病院でも，ヒヤリハット報告における医師の報告 割合が少ないことか問題視されていたところ, オンライ ン報告制度の導入によって , 医師の割合が $10 \%$ \%まで上
昇した . 報告が選択式であり，手近なP Cからいつでも 入力できるため, 報告か簡便になったことか要因と考え られる . また，紙媒体よりも報告から受信までのタイム ラグがく, 迅速な報告, 分析, 対応の流れができたと の利点があったという . また , オンライン上で, ゼネラ ルリスクマネージャーと, 診療科長 , 看護師長が同時に 情報にアクセスできることから，同じ情報を見ながら電 話でやり取りするといった運用上の利点もあつた .さら に，オンライン導入をきっかけに安全文化や現場の意識 形成に貢献したという効果も指摘された .

一方で，かえって不利となった点としては，オンライ ンで, 結果を返すため, 本人が觉の情報にアクセスしな い限り，結果を受け取ることができないこともあったよ うである .これには, 安全管理者から発信された情報を 受け取らないと, 自分の業務にアクセスできないなどの 技術上の対策が必要ではないかと考える。

\section{（2）医療安全管理室の整備}

報告に基ついた分析は，いずれの病院も月に一回の分 析小委員会で行い, 必要があれば, 委員会を随時開催す るという形式をとっている。医療安全対策室, 医療安全 推進室とよばれる管理部門が, 病院長の直轄として位置 づけられ，徐々に病院全体の認識も高まってきている .

平成 14 年から特定機能病院には専任のゼネラルリス クマネジャー(看護師が中心)の設置力義務付けられる . 医療機関によっては，医師と看護師，光れぞれの職種の ゼネラルリスクマネージャーをおいている . 過去には , 看護師のゼネラルリスクマネージャーのみで運営してい ることもあつた . 開始当初は, 看護師のゼネラルリスク マネージャーか現場に出向いても, ベテラン医師にきち んと事情を説明してもらえなかった，ということもあっ たようである . 最近は, 医師のゼネラルリスクマネージ ヤーがいことと，管理室自体の認知度の向上て仕事が しやすくなったというのがおおむねの感想であった .

ただ , 医療安全対策には, 物品の購入や新しいソフト の導入といったお金のかかることも多い.しかし, 病院 の予算の制約から，お金のかかる対策は導入困難なのが 現状である .これには, 医師・看護師といった現場をバ ックグラウンドにしたメンバーだけでは限界がある.光 こで, 経理や経営担当といった事務方のメンバーの協力 や理解を得る必要がある。

また, 安全管理室は,立ち上げから数年たち, 現在, 2 代目 ,3 代目のゼネラルリスクマネジャーになっている. 初代のゼネラルリスクマネジャーが作り上げた文化を， いかに承継していくか, 現場といかに整合性を保ってい くか, 引き継ぎの問題か現場では大きいようである .こ れには, マニュアル作成や，医師・看護師の二人の交代 時期をずらし常に全体を把握している人員を確保する， 
などの対策がとられている .

\section{(3) 報告内容の分析}

インタビューを行った医療機関の一つにつて，ある 月を例にすると，報告件数は月に 380 件ほどあった . 内 訳としては, 注射・輸液に関するものが $34 \%$, 投薬に関 するものが $23 \%$ と位を占める . 原因には , 見落としや うっかり忘れたというもの, 確認照合をしなかったとい うのが40\%を占めていた . また , 患者の取り違えとして 分類されるものか報告数の $5 \%$ ほどあつた . ただし , こ れには配瞨の間違い, 行為末実施など患者に影響の出な かったものも含まれており, 実際の数としてはかなり少 ない.しかし，この結果を医療機関は真摰にうけとめて おり, 再確認やダブルチェックというプロセスのマニュ アルの徹底，「確忍」のシールやタグを目に見えるところ に貼るという対策がとられた . また, 輸液ポンプのラベ ルに, 最終確認を行った人のサインやチェックをいれる といった対策を行った . ラベルののチェック印の導入で は, 点滴の取り違え件数を大きく減少させるという成果 を挙げている，弚れでも，慣れやうつかりといった，人 間の本質部分への対策は難しい。しつこい」管理者によ る目配り・気配りが，継続的に必要となるのであろう．

また，転倒・転落は，毎月 70-80 件起こっている.看 護師がきっきりでいられれば 解決できる部分もある . しかし, 業務負担の多い実際の現場では, 有効な解決策 ではない，また , 患者が自ら動いてしまっている事故も 多い、転ばない対策よりも，転んでも怪我をしないよう ハード面での対策が重要との指摘もあった .

\section{(4) 大学病院 $の$ 特色}

大学病院の特色として, 診療科の独立性力強いことが ある. 歴史や伝統のほか, 職域や診療科ごとの人事制度 にも由来する . 病院スタッフにとって , 所属する科長の 権限力強く病院長による病院全体の統率力取りづらい， 診療科ごとに異なったルールか存在し, 病院としての統 一か泪れない,といったこともあったようである .また， 医師が 3 ケ月程で入れ替わつたり，非常勤医師か外来を 勤めるなど人材交流も多く，マニュアルや指示の徹底が 難しいことも安全対策室の悩みとなっている .

さらに, 教育機関としての役割も持っているため, 研 修医や新人看護師の教育時期となる 4 月は特に業務負担 が多い. 新人看護師であっても，診療報酬上は, 一人の 看護師に相当するため，業務の不足分は，周辺の看護師 か補っている.ただ，4 月は, むしろ気を引き締めて頑 張るので, むしろ, 慣れてきた頃の月のほうがミスが多 いことも，事故報告の中身て明らかになってきている．

独立行政法人化によって, 診療科独立の動きは, 弱ま ってきたとの意見も多少聞かれた . しかし, 病院長の熱
意と安全管理室の存在で, 病院全体の連携を呼びかけて いるのカ現状である .

\section{2. 院外強制事故報告制度}

\section{(1) 医療機能棓平価機構への強制報告}

厚生労働省は, 平成 16 年 10 月 1 日より，国立病院， 大学病院などの特定機能病院に対する, 強制的な医療事 故報告制度を開始した . 報告先は, 財団法人医療機能評 価機構・医療事故防止センターで, 全国 276 機関が炎の 対象となっている. 報告義務のある医療機関の病床数総 計は, 147.986 床である (平成 17 年 3 月 31 日現在). ヒ ヤリハット報告も, 平成 16 年 10 月より, 医薬品機構か ら, 医療機能評価機構へと移行された .

また，医療機能評価機構は，評価事業の一環として， 認定医療機関に対し，事故報告の義務を課している .

\section{(2)医療法の根拠}

事故報告の義務付けは，医療法施行規則第 9 条の 23 ， 1項 2 号および, 同 12 条を根拠としている.医療機関は 事故事案力発生した場合, 事故報告書を事故発生から原 則2週間以内に，事故等分析事業機関に提出すること， とされる . 集めた情報は , 責任追及に利用しないとして いる.しかし, 医療法 29 条 4項は, 医事に関する不正や 業務に関する報告を怠った際には特定機能病院の承認を 取り消すことができるとする. 特定の取消し権限を有す る厚生労働省に，どのように事故内容が伝わるか，また， 報告を怠ったことにより特定を取り消されるならば，ど こまて報告を行えば忩ったことにならないのか，炎の限 界は医療機関にとって大きな問題である .

特定機能病院の取消しは, 事故報告を急った場合で， まだ発動されてはいない.しかし，今年6月東京医大， 東京女子医大が，相次いて医療事故を理由に，特定の承 認を取り消されている.承認取り消しによる損失額は， 年間3〜 4億円に上るともいわれる. 特定機能病院にと って, 大きな威㬨効果をもちうる規定であるといえる

\section{(3) 報告書の検討}

医療事故報告制度の第一回報告書が , 開始から半年後 の平成 17 年 4 月 15 日に公表された . 今後, 3 力月に 1 度のペースで報告書を発表する. 報告義務を課された医 療機関以外にも，任意参加の病院もあり，登録医療機関 は 533 施設である.これによれば, 平成 16 年 10 月から 平成 17 年3月 31 日までに, 533 件の報告があった .

報告件数は, 月に 100 件前後となっている. 事故の程 度は, 障害の残る可能性か低いケースが 254 件で半分を 占めたが , 死亡にいたるものも 83 件に上った .

コード情報や記述情報には，未選択，未記入の部分が あり，分析か不十分となっている.コード化情報では， 
特に患者の年齢, 性別などの患者情報の未選択率が $30 \%$ と高く, 医療当事者の職務経験, 部署の配属期間, 勤務 形態といった情報の未記入率も $20 \%$ を超えている.これ は個人情報保護法を意識したものと分析されている.記 述情報で，実施した医療行為の目的の未記入率が $23 \%$ と高い、ただ，この実施した医療行為の目的は，転倒・ 転落などでは目的の記入は難しいし，また，医療行為の 目的は基本的には治療目的であろうから, 何を書かせた いのかはっきりしないことに原因があるのではないか， と思われる .

むしろ, 記述されていても記述量が少ない, 重要な記 述の不足, 事実と推定の混在が , 事故報告の意義の根本 に関わる問題である. 事故発生から 2 週間以内での十分 な分析力難しいこともある . 追加報告が , どれくらいな されているか, 追加報告て改善提案がなされているか， も見る必要がある。

個別の内容としては「手術などにおける異物残存」,医 療機器の使用に関する事故」の二つの形態については， プロジェクトチームにおける分析が付されている ただ， 報告制度自体は始まったばかりであり，統計情報の報告 書に留まっている. 数も多くないため, 医療機関や患者 か特定されないよう配慮する観点からもやむをえないと いえるであろう .

\section{3. 光の他の院外報告制度}

\section{(1) 文部科学省への報告}

国立大学病院は, 文部科学省高等教育局医学教育課大 学病院支援室 (平成 16 年 4 月以前は, 大学病院指導室) への報告も行っている.平成 16 年 4 月以前, 国立大学病 院にとって, 文部科学省は管轄の長であり, 訴訟か起き た場合, さらには, 賠償責任か確定した場合, 文部科学 省力関与することとなる，乥こで, 監督機関に対する報 告という形式をもっていた 大学の独立行政法人化の後， 文部科学省は，管轄・指導の立場ではなくなったが, 支 援の形で , 事故報告を受けている. 大学病院支援室は， 現在 10 名て構成されており，主な安全担当は病院第一係 の2名である 一件の事故には，一人の担当官の判断と， 产の後に担当者が専門家に意見を聞くことになっている ため，狭い範囲の意見で，事故報告の内容の判断力行わ れている可能性があるとの指摘もある.ただ, 大学病院 にとっては身内として, 非常に熱心に医療事故対応をし てくれる, との感想もきかれ, 大学病院としては, 積極 的に報告を行う相手のようである .

\section{（2）地方公共団体への報告}

地方公共団体の単位で行っている報告制度として, 東 京都医療安全推進事業がある. 東京都が, 社団法人東京 都医師会に実施を委託した事業で,平成15年9月1日よ
り都内全病院に対象を拡大して実施される.現在, 東京 都内の 216 病院力参加している (平成17 年6月現在). ホームページで, 事故報告の統計情報だけでなく, 啓発 ビデオの公表を行うなど, 内容も充実しており，今回の インタビュイーからはよし評価を得ていた ${ }^{2}$.

\section{(3) 学会単位での報告事業}

学会単位の報告制度としては, 日本麻酔科学会「イン シデントレポート」「麻酔関連偶発発症例調査」, 日本泌 尿器科学会「医療安全評価」, 日本産婦人科医会「医療事 故・過誤防止事業」がある. 麻酔科, 産婦人科といった 訴訟リスクの高い学会が中心なって取り組んでいる。

学会からの, 指導・锥告を行い, 従わない場合は, 学 会からの除名も行うなど自浄作用としての効果をもって いる 。

\section{（4）警察への異状死届出義務}

患者の死亡力潩状死にあたる場合には 医師法 21条に より，所轄警察署への届出力義務付けられる。

医師法 21 条の届出を怠れば罰則か犐される .さらに， 警察への届出力㣜事捜査の端緒となるとしても, 憲法 38 条 1 項に違反しないとした都立広尾病院事件判決 ${ }^{3}$ がで たことで, 医療機関の関心は高い .

この届出義務に対し，19医学会から共同て第三者機関 の創設力要求されており，2005 年 9 月より，1億円の予 算をかけ，厚生労働省モデル事業として開始されること となった . 診療行為に関連した死亡の調査分析モデル事 業で, 医療関連死について, 患者遺族の同意を得て, 解 剖し，死因を究明する制度である.モデル事業の段階で あり 異状死届出義務は依然として残るが将来的には， 異状死と刑事捜査機関力運用として切り離されていく可 能性がある。

\section{4.医療機能容平価機構への評価}

厚生労働省による強制報告制度において報告先とな っている医療機能評価機構にはどのような評価かなされ ているのであろうか。

\section{(1)医療機能誩平価機構の評価体制}

日本医療機能評価機構は, 東京都の私立病院会 (現在 (東京都病院協会) の青年部会の医師が中心なって， 米国 JCAHO(Joint Commission of Accreditation for Healthcare Organizations )の医療機能評価の勉強を始めた ことか前身にある.これが全国規模に対象を拡大し, 任 意で評価を行う医療の質研究会となった . 時期を同じ くして, 日本医師会で評価委員会の存在や厚生労働省 から独立した第三者機関の必要性の議論か高まったこと も設立の契機となった .

当初は, セルフチェックの形て評価項目の数も 100 項 
目で,ピアレビューとしての色彩か強かった .しかし， 組織が大きくなり，また，評価を行う第三者機関として の役割力増大するにつれ，評価項目も500 まて増えた 。 具体的には, 当機構から派遣される医師, 看護師など から構成されるサーベイヤーか調査し, 評価を行う .こ れにより，医療の質を高めることを目標としている．出 資金は, 厚生労働省, 日本医師会をはじめ, 評価される 医療関係者によって運営されていることから，第三者性 や独立性に関する疑問力提起されることもある．

しかし，一方で，医療機関を評価するには，高度な専 門知諳力要求され，また，組織の維持のためには，医療 の質確保に関心を有する医療機関の関与を否定し得ない． そこで, 客観的な第三者性よりも，むしろ, 評価結果の 透明性や, プロセスの公正さなどの実質を検討し, 判断 することが重要である .

\section{(2) 医療機能容平価の問題点}

医療機能評価は，現在，1595 医療機関が受けている (2005 年 4 月現在). 病院 (20 床以上の有床の医療機関) は, 現在 , 9055 機関あることから , 病院の 2 割力認定を 受けていることになる (病床数は 1630461 床·平成 17 年 2 月医療施設重態調査) .

医療機能評価機構が, 事故報告を受け止める仕組みを もつ為にも，また，医療機関を適正に評価する仕組みと しても十分な機能をもつか, 力㵍題となる .

まず,評価の質について，500 項目を光ろえ，6名の サーベイヤーが ,2-5 日かけて調査する .この項目には， 患者の権利項目も含め, 多くの改良がされている.し かし,やはり外部評価の宿命として, 客観的な基準でし か判断できないという問題は残る . 医療機関は, 有する 機能によって，受け入れる患者の重症度や提供できる医 療にも幅がある . 乥こで, 患者の入退院率や死亡率など の数值で, 一概に評価できないことになる.このいわゆ るケースミックスの補正を行うことカ評価機関には求め られる.しかし，この評価方法の研究は世界的にも十分 にすすんできてはいないii)

また，認定機関を増やすために，医療機関に評価を受 けるインセンティブ付与を行ったことも一つの問題を生 んでいる.2002年の診療報酬改定において, 緩和ヶア病 棟入院料加算要件に医療機能棓平価の認定か要件となった . これによって，認定を希望する病院力増えている ${ }^{4)}$.こ れ自体は望ましいことである.しかし, 診療報酬は次年 度の医療機関の財務計画に大きく影響してくる. 認定を 重ねるうちに, 認定を外すことは医療機関にとって大き な打撃となる . 乥こで, 認定がとれない場合の留保と， 認定の間に，条件付認定という制度を生む原因となった． 評価機関がインセンティブ付与をきっかけに，医療機関 に対し，一種の経済的配慮を行うこととなり，機能評価
の形骸化を招く恐れがある．

\section{4. 報告制度の問題点}

\section{1. 報告対象について}

インタビューを行った結果, 医療機能棓平価機構か行っ ている事故情報の收集事業に対する医療機関からの評価 はあまりよくないように思われた .

医療事故か起きると，医療機関の内部において事故調 査委員会を設置して調査を行う.内部であるからこ光の 情報入手か河能となるが, 一方で, 外部である第三者機 関の調査には限界がある.外部機関でも入手可能な情報 から得られる分析では, 現場にどれだけ意味のある情報 となるのか，疑問であるとの声もきかれた . また , 国レ ベルでの対策が必要だと思うものだけを選んて提出対象 とすべきではないか, という意見もあった .

また，対象病院は，特定機能病院に限定されている. 特定機能病院に限定したのは, 国として統率の取りやす さ, 運営上の扱いやすさ, などがある.しかしすでに， 特定機能病院としての認定をうけるまでに,一定の機能 を整備することか要求されている. 兴の上さらに, 義務 付けの項目か増えることへの反発が見られた 。

\section{2. 院外報告の意義}

前述のように，院内て検討して，院内で対策をとればよ い事例について , 院外に報告する必要はないのてはない かという意見も聞かれた . 院外報告を行っても，報告先の 担当者から「このような対策をとればよかつたですね」と いう意見は，院内でもすでに対策か取られているか，検討 対象となっているものばかりで, 目新しいことか期待でき ない, という不満か背景にある。

一方で，院外報告，特に，国の関与のある機関に報告す るには, 院内での対策では, 不十分なものについて, 政策 的な対応力期待される.

具体的に医療機関の内部では，十分に対策できないもの として, 次のようなものか挙げられた .

まず，内服薬と注射薬て処方箋の書き方が違うことで ある.注射薬は1回に投与する量て指示をするため, あ る薬を朝 9 時と夜の 9 時に投与する場合, 朝 9 時に1グ ラム, 夜 9 時に1グラムという書き方をする .一方，内 服薬は，1日で何錠飲むか, 何回に分けるかという書き 方をする.乥こで，1日6錠，1日3回と書いてあると， 1回 2 錠と計算することになる . また, 粉薬は, 先進諸 国では日本にしかない薬斉の出し方であり，これには総 量のグラム数と分ける回数が書かれる.この違いは忙し し現場で混乱を生む原因となる．

光こで, 書き方を一回分に統一するというという病院 
内の対策がなされていることもあるが. しかし，入れ替 わりの多い大学病院では徹底されるの力灘しい，処方箋 の書き方は, 調斉の歴史とも絡み, 病院内で, どちらか に統一させること自体難しいということもある . 結局 , 書き方の異なる処方箋がランダムにやってくる医療現場 では, 最終確認は, 看護師の処理能力に依存することと なる.このような事例二光，国として統一の基準を出し てほしいという意見があった .

また , 薬㶡のアンプルのキャップの色は, 濃度によっ て黄色や赤などに色分けされている .これは, 製薬企業 の投資と努力でなされている.しかし，大きな病院だと， 同種の薬斉も，数社から取り寄せることもある.乥こで， 同じ薬斉の同じ濃度でもキャップの色か潩なったり，逆 に, 濃度か潩なる薬阁小のに, キャップの色か洞じであ ったり，かえって紛らわしいという現象もおきる.また， 手術て使用するポンプや機器の滅菌物の表示も各社バラ バラで, 医療者として, 袋のどこまて開けてよいのか， で迷うこともある.アンプルの色など, 企業か独自で行 うことは評価されるものの, 各社に統一かないことで, かえって現場に混乱を招いている.しかし, どのメーカ 一に合わせるか , の標隼化には難しい . 光こで, 全体の 統一基隼がガイドラインのようなものでも示されればよ いのに，という意見がきかれた .

院外報告の事例ては，このような現場の不満や, 矛盾 を全国の基準として解決可能な点力魅力なのであり，こ のような具体的な提言にむすびつくような事故報告制度 を期待したい .

\section{3. 現場と行政担当の意見の合致}

医療の現場からは，現場の対策や院内報告だけでは，対 応できないものについて, 院外報告て取り上げてほしいと いう意見があった．現場からは，もうすでに医療事故の傾 向は大体分っているのではないか.これからは,これまで 出た傾向をもとに，具体的な政策や制度提言を行う時期で あるという意見もある.また，行政の担当者からも，院内 だけでは継承しきれないもの，ママスとして還元すべき事例 を取り扱うことができるような工夫が必要であるとの意見 があった .この点 , 医療現場と行政担当の意見は合致して いる。

一方 , 行政からは , 医療機関の中には事故分析の努力を 国に任せきりの場合もあるのではないかとの指摘された . 特に，ヒヤリハット報告に関しては, 平成 16 年4月から 報告対象医療機関を全医療機関に拡大したことにより報 告数か急増している.もともと 250 力所程度だったものが, 平成 17 年 2 月 1 日現在で1, 263 力所になっている5 .乥う すると, 数が多すぎるばかりでなく, 報告の質や内容にも 格差がでる. 報告を受けたのちの加工に手間かかかるとい う問題も行政側から指摘された . 報告のレベルや , 報告者
の質確保，教育などもあわせて行うべき課題である .

報告制度の質を高めるには，医療機関，国双方での役割 分担と歩み寄りが必要であろう.

\section{5. 医療政策の失敗と背景要因}

\section{1. 医療資源は不足か}

医療現場ての具体的な安全対策と克服すべき問題点を 調査すると, 上位に医療スタッフの不足か学げられた . この人不足は, 都心よりも地方の病院でより深刻な問題 として捉えられている.もちろん, 人が足りないから安 全性が保てないというのは, 現場での努力を放棄した， ともとられかねない . しかし, 現場の実感としては, 非 常にスタッフか忙しく，十分な磪忍や対応まで手が回ら ないというものである.この実感は, 現場の一つの意見 として, 重要であろう.

このスタッフの不足の背景には, 診療報酬制度による 医療の包括評価, 医療費削減による在院日数の短縮化, 病床数を基礎とした一律のスタッフ配置基準があること か指摘できる。

\section{2. 包括診療報酬制度の影響}

2002年度の診療報酬改定により，2003年 4月から，特定 機能病院等に対する包括診療報酬制度力導入された . これ は，1860 種類の診断群分類 (DPC) による一日あたりの定 額を決めた点数に, 各医療機関別係数等を乗じて算出され る.全てが包括されるわけではなく，入院基本料，検査 (内 視鏡検査を除く)，画像診断，投薬，注射，処置 (1000 点 以上を除く) が包括の対象となり，手術料，麻酔料，1,000 点以上の処置料, 内視鏡検査，指導管理料，リハビリテー ション, 精神科専門療法等は出来高払いである . 医療提供 の基本部分が包括診療報酬の対象となることで, 診断名で 支扎われる額力決定される．乥こで，同じ疾患名でも，高 難度で手間のかかる患者が多い医療機関にとって大きな負 担となる。

また, 在院日数の短縮化によって, 従来の緩やかな入退 院のケアを経験してきた医療従事者にとっては，濃厚なケ アを必要とする状態䋡切れることなく, 訪れることにな る.これに対し, 必要な医師数や看護師配置は, 国によっ て一律に決定されている. 光こで, 濃厚かつ高度な医療提 供の期待される大学病院や特定機能病院には, 酷な結果と なっている。

\section{3. 医師・看護師の数は事実少ないのか}

医療現場て働く医師，看護師にとって，スタッフ不足の 実感があるものの, 実際に, 日本には医師・看護師の数が 少ないのであろうか. 
下記Fig. 1 は, 日本の医師, 看護師数の推移と国際比較 を示す .これによれば，人口当たりの医師の数が世界的に 極端に少ないとまではいえない，また，むしろ，看護師の 数は米国よりも高い水準にある.

Fig. 2 ては, 日米の医師・看護師产の他の病院従事者数 の人口当たりの比較である . 医師の枠組みをどのように捉 えるかによって , Fig. 1 , Fig. 2 では, 数值に違いはある ものの, いずれも, 日本は医師・看護師数において, 人口 における割合が少ないわけではないように思われる.対し， 谷の他の病院従事者数は極端に少ない。

乥れでは，なぜ人不足が深刻となるのか.これを示すの は, 病院数と病床数の多さである (Fig. 3) . 日本は人口あ たりの病床数力極めて高い，乥こで，医師・看護師あたり の受け持ち病床数が過大となり，マンパワー不足を生んで いると考えられる .

Fig. 1 医師. 看護師数の推移および国際比較 (人口 10 万人当た り)

鈴木征男の

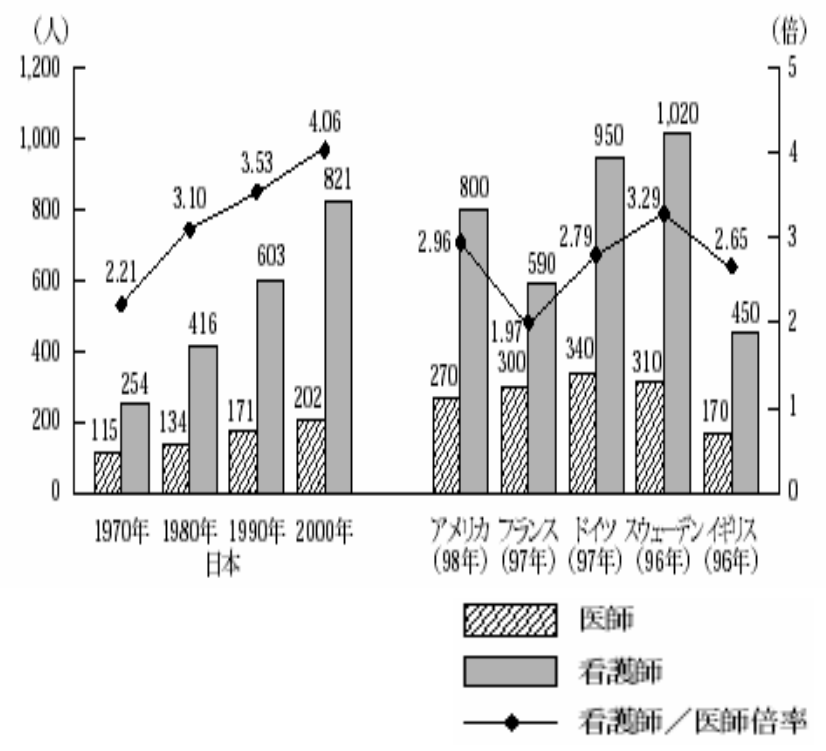

\begin{tabular}{|l|l|l||l|}
\hline & 日本 & 米国 & $\begin{array}{l}\text { 本/ } \\
\text { 米国倍率 } \\
\text { (人口比 })\end{array}$ \\
\hline $\begin{array}{l}\text { 病院従事の䀢 } 173,858 \text { 人 } \\
\text { 師・歯科医師数 }\end{array}$ & 191,238 人 & 2.0 倍 \\
\hline $\begin{array}{l}\text { 看護師・准看護 } 727,643 \text { 人 } \\
\text { 師数 }\end{array}$ & $1,178,845$ 人 & 1.3 倍 \\
\hline $\begin{array}{l}\text { 乥の他の病院挝 } 698,965 人 \\
\text { 業者数 }\end{array}$ & $3,128,444$ 人 & 0.5倍 \\
\hline $\begin{array}{l}\text { 合計病院従業者 } \\
\text { 数 }\end{array}$ & & & \\
\hline
\end{tabular}

Fig. 2 医師・看護師・产の他病院従業者数の日米比較

岡部陽二》

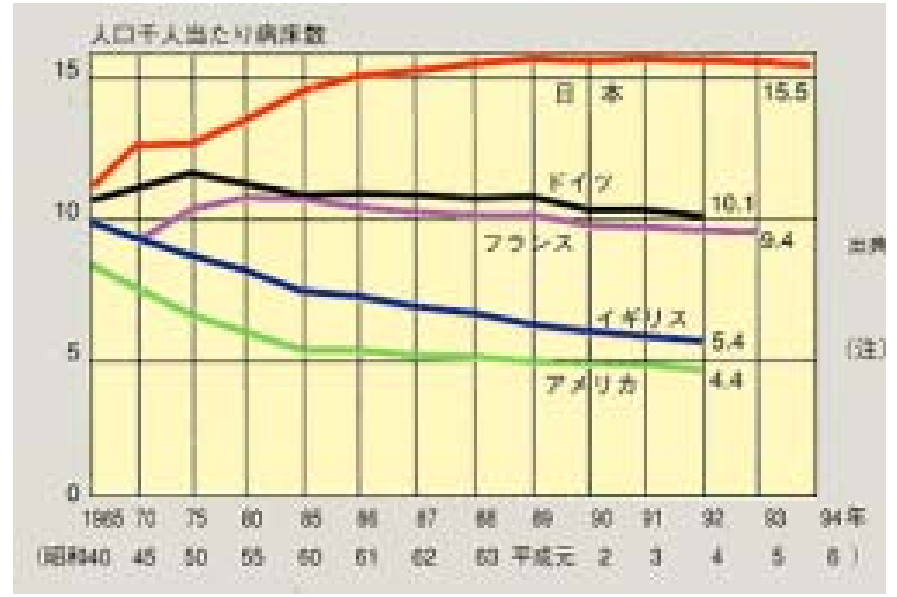

Fig. 3 各国の人口当たりの病床数 (厚生労衝省 ${ }^{8}$ )

以上から，日本のマンパワー不足は病床数あたりの医師， 看護師の数が少ないことと, また, 医療補助者か不足して おり, 専門業務以外に業務負担が多いとか指摘できる. 光 して, 現状の医療従事者数て医療を提供しようとするなら ば, 解決策として, 病院数や病床数を削減するか, 医療補 助者の増大力期待されるといえる .

「医師の需給に関する検討会」報告書 (平成 10 年 5 月 15日) において, むしろ, 将来的には供給医師が必要数を 上回ると報告されている . 全体の医師・看護師が , 総数で 十分確保されていても，専門分野による偏りや地域格差が 大きい.文部科学省によって, 各県に大学病院力配置され， 医療従事者の数を確保している.一方で, 光の次の配分の 段階で炎の数力㹬かされていない，厚生労働省と文部科学 省の連携不足ともいえるが，この状況下で，地域病院や専 門医の努力て医療は支えられている .

\section{4. 医療補助者不足の要因}

\section{(1) 医療補助者への報酬平価の不足}

医療の提供には，医師による治療や，看護師による療養 看護が兴の業務の中心となるのは事実である . しかしなが ら, 光の周辺業務として, 電子カルテ, 診療録, 各種記録 への入力, 記載, 紹介状の記入, 伝票整理・伝票運搬, 書 類整理・運搬 , 報告書の作成，院内会議なと数々の周辺業 務がある。

米国 I OMの調査では，看護師が全体の勤務時間の30\%近 くを，業務以外のペーパーワークに費やす看護師もいると のデータがある 9 . しかし，このような周辺業務に関して は, 診療報酬の対象として評価されてはいないし，また， このような周辺業務を請け負う, 医療補助者への報酬点数 か配分も不十分であると思われる. 医師・看護師が, 通常 の業務をこなし，一方で周辺業務も行うことで, 過重労働 に陥っている。

\section{(2) 付添婦の廃止}

療養看護には, 点滴や投薬, ケアといった看護の専門知 
識を必要とする業務のほかにも，食事の誤嚥のないよう付 き添ったり，トイレなどて転倒しないように付き添う見守 りという業務がある。

このような見守り行為に, 看護の業務の多くがさかれて いるのか実態である .このような見守り行為が，歴史的に 看護師か行ってきたか，というと必ずしも光うではない．

過去には，付添婦と呼ばれる無資格者が，患者や患者家 族の希望により，患者の見守り行為などのケアにあたると いうことがあった．しかし，患者の経済負担を軽減し，専 門家による医療サ一ビスの提供により，公平で, 質の高い 医療提供力叫ばれ，平成 6 年社会保険改正で，付添婦か完 全に廃止された。

これにより，資格を有する看護師による基準看護か実現 した . 当初 , 看護協会にとっても , 自らの職域を守るもの でもあり，職の安定と権威によって看護の質を保つという 考えがあったのではないか，と思われる．

しかし，この付添婦の廃止と基準看護の実現によって， 看護職人員を増加させることになり，病院の人件費の増大 を招いた . 人件費を抑えるためには，できるだけ，少人数 で同じケアに当たらなければならない，また，看護の手の かかる重症患者を，他の病院に移すという対応もおこるこ とになる . しかし，重症患者を受け入れることを使命とす る大規模病院にはしわ寄せがくることとなった .

\section{(3) 医師法 17 条による医行為の制限}

医療補助者が十分確保できない背景には，医師法 17 条の 「医師でなけれは医業をしてはならない」という非医師の 医療行為の禁止の規定もある。資格を持つ医師に医業を独 占させることで, 医療の質の安定を図る規定であるが , こ の中の「医行為」の解釈により，在宅医療の介助者や医療 補助者との業務分担力灘しい状況にある.

しかし，近年，この状況に限界があり，いくつかの検討 会て医行為の解彩の限定や，医業独占からの開放力行われ ている.例えば,ホームへルパーによる痰吸引は，03年 ALS 患者への一部開放から，05年には脊骾損傷や脳血管の疾患 患者など少なくとも1万5千人の患者にも対象力昿大され ることとなった(03年 7 月 17 日厚生労働省医政局長通知， 05年医政局通知）.また，爪切りや湿布の貼り付け，軟亳 塗布, 座薬挿入, 浣腸などか原則的に医行為から外される こととなった（2005年 3 月 31 日厚生労働省方針解説; 朝 日新聞2005年 3月 31日夕1面) .

光のほか, 救命救急士の業務拡大 (救命救急士法施行規 則第 21 条) , 除細動器の航空機への搭載 (01 年 12 月 19 日航空業界の質問に対する回答) など，同樣の動きは多方 面で見られる . 医行為の開放によって，医師には医師しか 行えない医療行為に集中させ，濃密なケアか期待される . しかし，一方では，ヘルパーへの研修体制もなく，また， 新たな責任問題も孕んでいる.

\section{6. 問題解決の方法}

\section{1. 各病院の取り組み}

\section{(1) 転倒リスクマップ (北大病院の取組み)}

高龄者が多く，また，抗がん斉治療を行っている内科病 棟では, 患者力転びやすいうえ, 骨がもろく, 転倒により 骨折することもある .一月の中でも転倒のインシデント報 告が 70 件前後あり，いずれの病院も大きな関心と注意を払 っている。

北大病院の内科病棟では, 患者の入院時に転倒リスクを チェックし, 重要度に点数を付けている。これによって， 特に注意の必要な患者と光うではない患者の区別を行い， 特に必要な患者に集中的に業務と精神を集中することがで きる.このリスクマップを導入したことで, 実際におきる 転倒数が減るところまでは至っていない. しかし, どの点 数がつい患者か実際, 転倒率が高いか, などか明示的に 分ってきたことで, スタッフの対応と連携がとりやすくな るという効果があった．また，実際に転倒事故か起きた場 合には，病院がどのような対応をとっていたかを説明する ことが必要となる.訴訟や紛争まで発展すればなおさらで ある.この転倒リスクマップは, 患者・患者家族に対し， 病院の対応を明らかにする効果もあつた .このリスクマッ プは, 医療安全推進室でも評価され, 脳神経外科など他の 診療科も採用している.

また，患者が起き上がると反応するセンサ一つきのマッ 卜など，機材の導入によっても，業務の軽減力期待される が，予算執行の都合でなかなか十分な導入ができないのが 現状である。

\section{(2) 人員配置の工夫 (京大病院の取組み)}

医療現場での業務分担を独自に行って成果を挙げたのは， 京大病院である.この背景には, 平成 16年度からの卒後臨 床研修の必修化があつた .この制度導入は, 研修医の深刻 な大学病院離れを生んでいる.制度の発足前は7割の研修 医が大学病院に残つたが, 現在では高給で待遇のいい一般 病院て研修を受ける医師が半数になったといわれる（毎日 新聞 6 月 8 日社説) . 京大病院でも，平成 16年の研修医募 集には定員に対し，十分な人数を確保できなかった．これ まで, 医療の周辺業務は, 研修医によって行われており， 研修医が行ってきた業務を誰がどのように分担するか , が 大きな問題となった .

弚こで, 京大では, 無資格の医療補助業務を行う医療補 助者と，時間給の看護師を採用することにした .この時間 給の看護師は，京都近辺に住み，看護師を長年努めたべテ ランも含まれていたようである .この時間給の看護師を， 外来の看護師として配置し, 光れまて外来に出ていた常勤 の看護師を病棟勤務に戻した . 常勤の看護師のローテーシ ヨンによって, 外来勤務を回していたのに対し, 固定の外 
来勤務の看護師を確保することができた . また，濃厚ケア の必要となる病棟に常勤の看護師のマンパワーを投入する ことができた .

さらに, 京大病院には, デイサージャリーという日帰り 手術部門に15人の看護師を配置し，日帰りもしくは翌日に 退院するという診療形態をもつ. また，膵島移植専門外来 では11例もの膵島移植手術を行っている ${ }^{\mathrm{iii})}$.

デイサージャリーという高度で, かつ迅速，経済的な負 担も少ない手術部門に多くの人員を配置することで, 京大 病院の特色を出すことができる．

研修医の給料として配分しておいた予算が余っていたと いう背景も一部あるようで, 他病院ですぐに同樣の対応が 可能とはいえないであろう . しかし, 補助者や非常勤看護 師を雇うことのメリットを十分証明したものといえる .

また，看護部の中で， 忙しい部署と比較的緩やかな部署 の間で , 人の配置に柔軟性を持たせるという動きもあるよ うである.このような流机は, 京大病院看護部独自の文化 として形成されつつある .

\section{2. データの収集}

\section{(1) 各病院での取り組み}

医療現場の安全確保に，人員の適正な配置や診療報酬が 十分でないことが多く指摘された . しかし, 乥れならばど のような人員配置が適当であるのか, 特定機能病院は, ど れくらい患者のヶアに時間かかかっているのか，また，機 能を十分果たすためには, どれくらいのお金が必要なので あろうか. 差別化を図るためには , 差があることを十分に 説得できる材料か必要となる.

医療機関は，看護必要度や病床稼働率など多くのデータ を持っている.例えば,東北大学病院で，看護必要度は， 看護師が毎日, 受け持った患者につき, ケアに何分以上か かったかの項目を入力し, 算出される.結果は, 看護部が 光れをデータとして集計して, 次年度の病棟ごとの看護配 置数を決めるときの参考にしている.このデータは, 看護 部蝐に集めて, 看護の配置に利用するのみである . 病 院全体のデータとして利用されたり，また，国立大学病院 や特定機能病院全体のデータとして利用されることはない ようである.また，病床稼働率は，単純な入退院の記録で， 事務的なものである.これらデータが, 病院の特色を現し たり，負担を示すものとして，加工されてはいない .

病院で収集されているデータは，もともと，政策提言を 目的に収集されたものではない，しかし，業務の合間を縫 って，入力された看護量などの情報を分析して，より有効 な利用はできないものであろうか. 自病院が, 他病院と比 べて異なることを，医療機関が自らアピールする一つのき つかけとはならないであろうか.これらのデータを政策提 言に結びつく形に分析・加工することで, 病院には，どれ くらいのお金と人が必要なのか, 医療機関の側から提示し
ていく必要があろう . 分析の部署というのは, 設置するこ とは難しいが, 光の機能を外部の経営分析や公衆衛生学の 分野の研究者力担っていけれは利用可能になるともいえる.

医療機関がどのような機能と特色を持っているのか，を 示す指標 (クリニカルインディケータ) も , データとして の機能力期待されるであろう .

\section{(2) 医療機能容平価機構の役割}

病床数の減らすことが一つ解決策になるが, どのあた りの病床数力㵍題か, 一つの検討材料となるのが, 医療機 能評価機構の役割があると思われる .ある病床数での認定 率か高い，あるいは光の逆に低いなどのデータが示される ことである . そして, 認定をとれないような医療機関を分 析し 統廃合の一つのきつかけにする可能性がある .ただ， この医療機能評価機構の病床数と認定率の関係に関するデ 一タを公開していない，また，乥も光も，医療の質といっ た内容の評価には限界がある. 先のケースミックスの事例 も同樣である . また , サーベイヤーの評価後, 評価者によ る差を補正するため, 総合評価プロセスを経由するが, 光

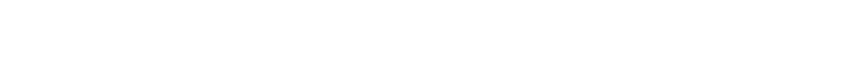
るといった運用上の問題点も指摘できる．医療機能評価機 構の第三者性と公平性, 専門性を生かした , データの収集 と提供が後一層望まれる。

\section{3. 医療安全対策への評価}

院内報告の整備には，医療機関にとって一定の意義と成 果を認めているものの，院外報告の義務付けについては， 医療機関にとっては，押し付けられた負担と捉えられてい るように思われる . せめて , なんらかのメリットとの引き 換えであったり，報告制度を整備したり，安全対策をとつ ている取組みを評価してほしいという思いがある。

例えば，米国ニューヨーク州で , 州の医療事故報告の義 務付けか制度化した背景には，医療過誤訴訟の増大による 保険色機があり，州政府力医師に対する費用補助とのトレ 一ドオフとして入れられたことか背景にある ${ }^{10}$.

押し付けられた制度のイメージから，質向上のための相 互協力の制度として育てていくには, 診療報酬制度への評 価などメリット制度の導入か釦討される必要もあるだろう．

\section{7. まとめ}

本稿ての検討は，国立大学病院インタビューをもとに 構成したものであり，多分にバイアスがかかっているこ とは否定できない，しかしながら, 国立大学病院力医療 産業の中で，また，社会にとって，大きな役割を果たす 当事者であることは事実であり，このような意見を抽出 できたことは一つの成果であると考える．医療現場の具 
体的な取組みや思いが, 十分社会に伝わってこなかった 現状からすれば,一つの前進である . 今後, 多くの立場 の意見を吸い上げ，医療現場と法制度の関係と連関を明 らかに，相互協力へと導きたい．

日本の医療政策には，国民皆保険という，全ての国民 か平等に医療を受けられる機会を保障する枠組みがある． 健康長寿国であるのも，この政策の生み出すところであ る。しかし，GDPにおける医療費割合か低いまま医療 機関の負担によって，医療制度か回ってきたという実態 も裏にはある．また，どこにいても平等に，いい医療が 受けられることか地域の評価と結びつくなど， 国民の要 求を医療機関か涭け止めてきた現実に限界もみえている. 医療事故報告制度を通して 医療機関ては 具体的に樣々 な取組みを行ってきたが , 一方で , 国として取り組んで ほしいことや，法制度改革として，取り組まねばならな いことも指摘できた . 今後の医療安全確保のためには， 現場と国，双方の協力を期待したい．

\section{参考文献}

1) 福島洋子 (2003)「北大病院における医療安全の取組み」 『ジュリスト』1245, 48

2) 東京都医療安全推進事業H P : http://www.tmsia.org

3) 川出敏裕(2004)「医師法 21条の届出義務と憲法 38条 1項」『法学教室』290.

4)「病院機能产価」(2002)『日経ヘルスケア』5月号 15,16 .

5) 厚生労働省 : 医療安全対策会議第 19 回議事録

6)鈴木征男(2002)「複杂隹な看護師の養成過程」『LDI $\mathrm{REPORT}_{2} 7$ 月号, 51 日本 : 厚生労働省「医師・歯科医 師薬斉师調査」看護師については, 同「衛生行政業務報 告」外国の医師については OECD 「Health DATA 2001」外
国の看護師については (財) 厚生統計協会 HPより

7) 岡部陽二「医療システムの日米比較」日本 ; 日本医療企 画「2001年度版・医療経営白書」所載の「中央社会 保険医療協議会「医療経済実態調査報告」より作成され た「民間・国公立別病院1施設当たり収支状況 (平成1 1 年)」に基づき岡部作成米国 ; America Hospital Association 編 , “Hospital Statistics”中の “US Registered Community Hospitals" の Revenue を使用

8) http://www1.mhlw.go.jp/topics/hoken/iryo5.html 日本「医療施 設調査・病院報告」炎の他「OECD HEALTHDATA」

9) I OM 2003) KEEPI NG PATI ENTS SAFE, 244

10）拙稿「医療事故情報システムの機能要件」『社会技術研究 論文集 Vol.2』297

\section{謝辞}

お忙しい中 , 快くインタビューに応じてくださった病 院の方々と，多くの有益な二意見を下さった社会技術研 究システム医療安全研究グループ, 法システム研究グル ープのメンバーの皆樣に心より御礼申し上げます．

i) 国立大学病院インタビューは, 三菱化学安全科学研究所 研究員の横山織江氏との共同で行った .

ii) 米国 CDC (Centers for Disease Control and Prevention) でケ 一スミックスに関する研究を行っている。

iii) 膵島移植とは, 血糖コントロールか困難な 1 型糖尿病あ るいは膵性糖尿病患者に対し, 膵葴内の一部を移植する。 平成 16 年 12 月に京大病院力世界て始めて実施し, 生体 膵島移植(親族・夫婦間) 1 例, 心停止ドナ一からの膵島移 植10例をすでに実施している。

\title{
THE HOSPITAL EFFORTS AND LEGAL SYSTEMS FOR MEDICAL SAFETY -MAINLY FOCUSING ON REPORTING SYSTEM
}

\author{
Ryoko HATANAKA $^{1}$ \\ ${ }^{1}$ LL.M(Law)Research Institute of Science and Technology for Society (E-mail:jj96130@j.u-tokyo.ac.jp)
}

\begin{abstract}
Medical Organizations strive to supply safety and high quality medicines every time. But that efforts have not been known by society, and we receive news of medical accidents and medical misconducts. This study aims to describe subjective hospital efforts and approach from the view point of legal researchers. The complexities of medical policy have much to do with legal systems, for example, disease related groups-based prospective payment system. This study advances the good relationship between medical organizations and legal systems to evaluate hospitals efforts, and medical policy in the future.
\end{abstract}

Key Words: Reporting system, Medical safety Policy, Allocation of medical resources, Accreditation for medical organizations 